\title{
The Northern Great Plains as Viewed by the Lewis and Clark Expedition
}

\section{By Don Kirby}

I $\mathrm{n}$ a few months' time, the Society for Range Management will again hold their annual meeting in the northern Great Plains in Billings, Montana. The northern Great Plains is a vast territory, mostly comprised of productive grasslands, rivers, isolated woodland, and wetlands, with a myriad of flora and fauna. It also is defined by a long list of adventures and adventurers beginning with the Native American tribes and continuing to the present day.

One such adventure, occurring just over 200 years ago, was the famous expedition led by captains Meriwether Lewis and William Clark. Between 1803 and 1806, on orders from President Thomas Jefferson, the two captains were to chronicle the people, landscapes, geology, and geography, as well as the flora and fauna they encountered in the northern Great Plains and beyond. It was an expedition of historical significance that has been discussed and revisited by scholars, scientists, and historians often throughout the past 200 years. This article is intended as a brief view of the northern Great Plains through the eyes and pens of the Lewis and Clark expedition as described in their journals. ${ }^{1}$

The majority of the expedition was comprised of 32 members. Only one member, Sergeant Charles Floyd, died on the trip, most likely from a ruptured appendix. One member, whom the other expedition members called Pomp, was born on the trip, to Charbonneau (an interpreter) and his wife Sacajawea (a guide). Two members enlisted after the start of the trip while two others were discharged from the party. What truly is amazing concerning the trip is that, despite the party being in the wilderness for two and a half years (April 1804 to September 1806) and encountering numerous hostile tribes, carnivores, storms, and much more, they did not lose a single member of the party to an accidental death. Most historians credit this remarkable record to the intelligence of leadership of the party, as well as the prior experiences in wilderness travel by the majority of the party.

On the trip west, the expedition crossed into present-day South Dakota approximately 24 August 1804 and into
North Dakota approximately 15 October 1804. They wintered in Mandan, North Dakota, and continued the trip the next spring, arriving in Montana approximately 25 April 1805. The expedition left Montana and traveled west into Idaho on 13 September 1805. In total, on their way west, the expedition spent over 1 year (55 weeks) or nearly $40 \%$ of their total time traversing the northern Great Plains of South Dakota, North Dakota, and Montana. It's noteworthy to contrast their trip home from the West Coast to $\mathrm{St}$ Louis: It took nearly a year and a half to arrive at the Pacific Ocean, but the expedition traveled back over nearly the same route in only 6 months.

The Native Americans that captains Lewis and Clark met in the northern Great Plains were mostly friendly and helpful. Many evenings were spent exchanging stories and information while smoking a pipe. The leaders of the expedition often exchanged meat, hides, corn, beans, squash, hominy, tobacco, and other goods with the tribal members. When wintering near the Mandan villages in 1804-1805, Lewis and Clark helped defend the villages from raiding tribes. In turn, the Mandans helped in the building of a winter camp for the expedition members. One big surprise of the trip that improved relations with the tribes was Clark's servant, York. As noted by Clark on 10 October 1804 "Indians were much astonished at my servant, they never saw a black man before." Many tribal members touched York to see if his color was real or painted on.

Despite there being few entries concerning plant communities in their diaries, the passages written described the majority of the northern Great Plains as mixed grasslands having few to no trees or shrubs except immediately along the Missouri River banks. A good example of this was when the party was looking for a wintering camp in 1804-1805. The expedition had to move down river a few miles because "wood was too scarce", even along the river, to build a camp. Another example was on their way west from their winter camp in the spring of 1805. Clark climbed to the top of a bluff near present day Williston, North Dakota, and wrote, "I had a most delightful view of the 


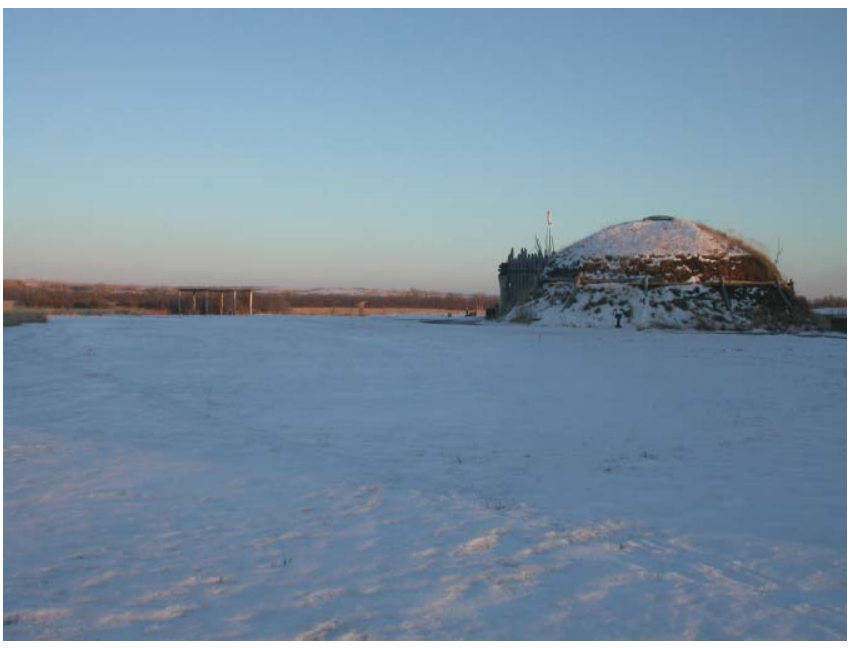

Recreated earth lodge at the Knife River Indian Villages National Historic Site, Stanton, North Dakota.

country, the whole of which is void of timber or underbrush." The plant communities viewed by the expedition members were not surprising, given the natural factors controlling plant populations in the plains such as grazing pressure and, of course, limited and variable annual rainfall that is common even today on the northern plains. In addition, the heat of summer and cold of winter puts limits to growing a large diversity of plants on the northern plains.

There are many other descriptions in the diaries allowing insight into the character of the prairie at that time. A week after leaving their winter camp, 14 April 1805, Clark notes "where the land is level, it is uniformly fertile ... it is generally covered with a short grass resembling very much the blue grass...." There is little doubt that Clark is describing blue grama, which today, when present in large quantities, we associate with overgrazing. Two entries in April 1805, "On the hills are many aromatic herbs, resembling in taste, smell and appearance the sage, hysop, wormwood (sagebrush)..." and "the ground is covered with a short grass (blue grama and/or buffalograss), aromatic herbs (sagebrush) and an immense quantity of prickly pears", give further insight into prairie conditions at the time along the river. Near the Judith River east of Great Falls, Montana, the diary entry read,

The soil is dark, rich, and fertile, yet the grass by no means so luxuriant as might have been expected, for it is short and scarcely more than sufficient to cover the ground. There are vast quantities of prickly pears and myriads of grasshoppers.

My favorite entries are two in mid-June 1805 at Smith's River and Great Falls, Montana, which read, "The whole country is so infested by the prickly pear that we could scarcely find room to lie down at our camp" and, while portaging the great falls of the Missouri, "The prickly pear annoyed us very much today by sticking through our moccasins." Finally, an entry near present day Helena, Montana, sums it up well:

Low ground has a fertile soil of rich black loam ... the drier situations are covered with fine grass, tansy, thistles, onions, and flax. The uplands ... only produce prickly pear, the sedge, and the bearded grass which is as dry and flammable as tinder.

Logically, considering the numbers of grazers, the climate, and the influences of farming, hunting, and the setting of fires by the Native Americans in the northern Great Plains, it is not difficult to surmise that much of the space and natural renewable resources of the region were fully utilized prior to European settlement.

Then we have fire. We know that fires can be set naturally by lightning strikes, yet fires were much more prevalent during the expedition's visit than would have occurred naturally. For instance, a prairie fire set by Native Americans on 29 October 1804 burned so fiercely and rapidly that a man and woman were both burned to death because they could not get to safety. On 30 March 1805, Clark wrote "The Plains are on fire in view of the fort (Mandan) on both sides of the river." Frequent fires would help explain the prevalence of grasslands void of trees and shrubs on the northern plains.

Wild game was abundant to the expedition. The diary entries often note plentiful quantities of a variety of game and waterfowl species. Lewis and Clark did not attempt to estimate bison numbers for the plains at this time, but others have estimated that anywhere from 20 million up to 65 million bison grazed on the Great Plains, mainly between North Dakota and Oklahoma, and then west to the Rocky Mountains. ${ }^{2}$ For example, starting on day one in North Dakota near the Cannonball River, where the daily entries read "great numbers of Goats (pronghorn antelope)", "gang of Buffalo bulls", "248 elk", and "our hunters killed 4 Goats, 6 deer, 4 elk and a pelican", to entering Montana where the day's entry read "game is still abundant we can scarcely cast our eyes in any direction without perceiving deer, elk, buffalo and antelope", wild game was abundant on the prairies of the northern Great Plains. One noteworthy entry on 23 April 1805, at the Little Muddy River near Williston, North Dakota, stated,

\section{I ascended to the top of the cut bluff this morning, from whence I had a most delightfull view of the country, the whole of which except the vally formed by the Missouri is void of timber or underbrush, exposing to the first glance of the spectator immence herds of buffaloe, elk, deer, and antelopes feeding in one common and boundless pasture.}

From this evidence, it can be surmised that there was significant grazing pressure on these northern prairies. As for the distribution of this grazing pressure in time or space, we only can guess that it would be somewhat seasonal and 


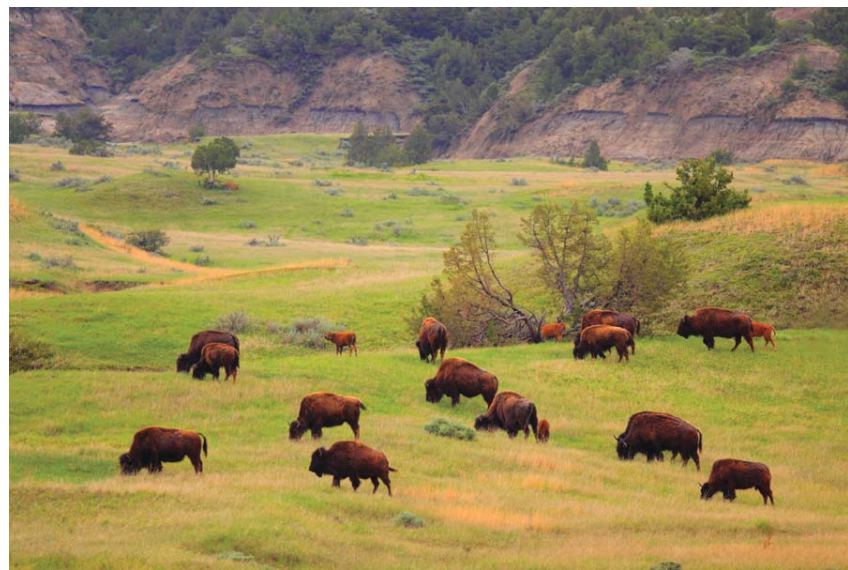

Bison herd along the Little Missouri River in Theodore Roosevelt National Park, Medora, North Dakota (photo by Kelly Krabbenhoft).

uneven, and strongly influenced by factors such as available forage, surface water, fire, drought, hunting pressure, and carnivores.

Evidence of the effects of land usage and natural disturbances on soil erosion was noted by the party along the Missouri and intersecting rivers. Clark wrote on 14 April 1805 near present day Ft Berthold, North Dakota, "The low grounds are wide, the moister parts containing timber, the upland extremely broken, without wood, and in some places seem as if they had slipped down in masses of several acres in surface" and "soon after we set out (20 April 1805) a bank fell in near one of the canoes which like to have filled her with water..." Two days later at the Little Muddy River near Williston, he wrote "the banks of the river are steep and not more than ten or twelve feet high; the bed seems to be composed of mud altogether...." One final entry from Sunday, 26 May 1805, near the Judith River in Montana, read, "The hills high and jutting in on both sides, to the river in many places. The stone tumbleing from these cliffs and brought down by the rivulets became more troublesome today." These conditions are evident even today. Nearly

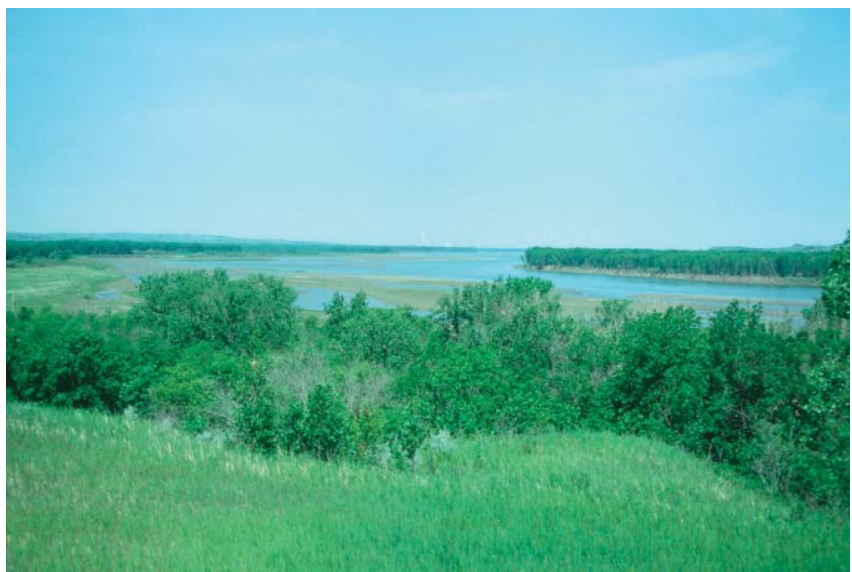

Present day Missouri River near the 1804-1805 winter encampment of the Lewis and Clark Expedition, Stanton, North Dakota.

every year there are significant and natural erosional events that take place in the northern Great Plains, particularly in the more arid portions of the plains.

Captains Lewis and Clark's journals are an historic treasure detailing the lands, peoples, flora, and fauna of millions of acres of wilderness yet to be discovered. What they discovered is what we now have settled, building cities and roads as well as farming and ranching of these rich lands of the northern Great Plains. For an easy read of the journey I recommend "The Journals of Lewis and Clark," as edited by $\mathrm{DeVoto} .{ }^{1}$

\section{References}

1. DeVoto, B. [ed.]. 1953. The journals of Lewis and Clark. New York, NY, USA: Houghton Mifflin. 504 p.

2. Seton, E. T. 1929. The lives of game animals. 4 vol. Garden City, NJ, USA: Doubleday, Doran and Company. 929 p.

Author is Professor of Range Science and Director of the School of Natural Resources at North Dakota State University, Fargo, ND 58105, USA, Donald.Kirby@ndsu.edu. 